\title{
EMPIRICAL STUDY ON ORGANIZATIONAL PERFORMANCE: THE MODERATING EFFECT OF ORGANIZATIONAL CULTURE
}

\author{
DOI: 10.17261/Pressacademia.2020.1295 \\ JEFA- V.7-ISS.3-2020(8)-p.287-297
}

\section{Muhammad Heno Rifdas Hafizh ${ }^{1}$, Khoirul Aswar ${ }^{2}$}

${ }^{1}$ Universitas Pembangunan Nasional Veteran, Jl. RS Fatmawati No. 1 Jakarta Selatan, Jakarta, Indonesia. muhammadheno@upnvj.ac.id, ORCID: 0000-0003-2782-1278

2Universitas Pembangunan Nasional Veteran, Jl. Duren Tiga Barat V, Duren Tiga Kecamatan: Pancoran, Jakarta Selatan, Indonesia. aswar_law@yahoo.com, ORCID: 0000-0003-2508-1161

To cite this document

Hafizh, M.H.R., Aswar, K. (2020). Empirical study on organizational performance: the moderating effect of organizational culture. Journal of Economics, Finance and Accounting (JEFA), V.7(3), p.287-297.

Permanent link to this document: $h$ ttp://doi.org/10.17261/Pressacademia.2020.1295

Copyright: Published by PressAcademia and limited licensed re-use rights only.

\begin{abstract}
Purpose- This study is based on IHPS BPK RI 2017 in the second semester. There are problems in terms of the performance of local governments in Lampung Province. The purpose of this study is to analyze the effect of 4 successful factors of AIS consisting: service quality, information quality, data quality, and system quality on organizational performance moderated by organizational culture.

Methodology- The population of this study is 29 Regional Apparatus Organizations (RAO) in South Lampung Regency using a saturated sample. Contingency theory is the basis of this study in order to form a mindset connecting four successful factors of AIS supported by the organizational culture of the leadership of the RAO on organizational performance. The analysis technique uses Structural Equation Model (SEM) through the SMART PLS version 3.0 application.

Findings- The results of this study indicate that there is a significant positive impact on organizational performance which has been presented by service quality. On the other hand, organizational performance is not influenced by information quality, data quality, and system quality. Whereas, the organizational culture does not constrain the relationship of service quality, information quality, data quality, and system quality on organizational performance.

Conclusion- This study concluded that service quality is positve significantly on the organizational performance. Whereas, the information quality, data quality, and system quality insignificant relationship with the organizational performance in regional apparatus organizations. Therefore, further studies could be conducted to include other variables such as employee motivation, employee performance, self-efficacy, in indonesian local government.
\end{abstract}

Keywords: Service quality, information quality, data quality, system quality, organizational performance, organizational culture. JEL Codes: H11, M41, M48

\section{INTRODUCTION}

The state as a public organizer obligates to meet the basic needs of the citizens. The basic needs consist of goods, services as well as administrative services. The public services provided by public service providers show the government system whether it is good or bad. The government organizes public services which represent the quality of the public bureaucracy. Therefore, the government ought to reform the quality of public services to get people's satisfaction. In this case, the government has a policy related to public services stated by the Decree of the Minister of Empowerment of State Apparatus (KEP/25/M.PAN/2/2004). It explains the general guidelines for preparation of Public Satisfaction Index in the government institution service unit. To improve the quality of public services, the government has formulated guidelines to improve the quality of public services involving the public stated in Law Number 25 of 2009 mentioning that everyone has the right to use the best public services. In accordance with Permendagri No. 13 of 2006, performance is defined as the output / results of various activities / programs to use a measured quantity and quality budget as the target. 
Problems with public sector organizations, especially in Indonesia, still occur today. The results of audits of the Supreme Audit Agency (BPK) in 2015 - 2017 have shown that the public service administration of Population Administration and the Office of Investment and Integrated Services remains very low. Sunarto (Head of the Lampung Representative Financial Auditing Agency) states that the poor performance quality of local governments is found in North Lampung, Central Lampung, South Lampung and Tulang Bawang.

One of the critical success factors of organizational performance is service quality. To achieve the success of an organization, there is one factor that is providing quality of service (Rahaman et al. 2011). According to Gowan, Seymour and Ibarreche (2001), to provide public sector services is sophisticated. It deals with meeting and finding out the needs, setting priorities, and allocating public resources. Public sector organizations are always pressured to provide service quality and improve efficiency (Robbbin \& Coulter, 2005). Service quality on organizational performance has a positive relationship (Ali et al. 2016; Duncan \& Elliot, 2002; Nazeer et al. 2014; Yasin et al. 2004).

Emery (1971) states that the information quality becomes the cause of a decrease in operating costs outside the information processing system. Hamilton and Chervany (1981) state that improving computer-based information systems can be done through corporate revenue. Bender (1986) examines the effect investigating financial information processes. It can be found that the quality of information has a positive-significant positive impact on organizational performance. The review shows that the quality of information and the performance of ERP system users have a significant relationship (Kositanurit et al. 2006). In line with this, a close relationship is found in the information quality and performance quality occurring in the public sector organizations (Ali et al. 2016).

Peltier et al. (2013) state two main ideas. First, high-quality customer data has impacted the customer and business performance. Second, the executive suite becomes the most important control of customer data quality. The quality of inputs, processes and outputs determines the result of effectiveness. This shows the essence of data quality for the success of AIS (Hubley, 2011; Wongsim \& Gao, 2010). The importance of data quality is the top priority in organizations. It also influences not only the organizational performance but also the adoption of accounting information systems (Ahmad et al. 2013; EmekaNwokeji, 2012). The study is not in accordance with Ali et al. (2016) which finds there is not any impact on organizational performance delivered by data quality.

The quality of the system is an information characteristic about the system. The quality of which the system refers to how well information about the user needs are provided by the hardware, software, and policy policies of the information system as stated by Delone and McLean (1992). The company is benefited with compatible high-quality software (Slaughter et al. 1998). Data warehousing situations with a system quality related to good benefits have been noticed from the productivity of individuals which ease the decision determination (Wixom \& Watson, 2001). The system quality is related to the organizational performance in the company at the operational level in a positive way (Bradley et al. 2006). Seddon and Kiew (1996) describe the system quality related to the perceived benefits becomes significant. Generally, the existing relationships between the system quality and the benefits have been summarized in part by the literature. The related relationship between ease of use (even though it is perceived as a benchmark for the quality of the system) and the perceived benefits are mixed. Some studies found that the system quality performs a positive relationship with the benefits of an organization (Hsieh \& Wang, 2007). In line with the public sector, the system quality influences organizational performance (Ali et al. 2016; Bharati \& Chaudhury, 2015). However, there are also those which deliver no effect (Shagari at al. 2017).

This study applies organizational culture as a moderating variable. It is because the organizational culture and the organizational performance deliver effect on one another. There is a positive relationship between organizational culture which leads to results related to the performance (Verbeeten \& Spekle, 2015). Performance management triggers the emergence of unique cultures in public sector organizations. It ripples significant effects developing the performance of public sector organizations (Parker \& Bradley, 2000). Henri (2006) claims that organizational culture is a strongly built performance management practice. It also serves as a major determinant of the performance of public sector organizations. An effective organizational culture is a well-known and familiar construction. It plays an important role to promote good institutional practices and achieve efficient results (Ramachandran, Chong, \& Ismail, 2011). In the same order, Kanji and Moura (2007) argue that institutional culture influences functional patterns and organizational performance. Melkers and Willoughby (2005) specifically postulate that flexibility in cultural norms and good cultural tendencies enhance the performance of public sector organizations. Wong et al. (2012) suggest that organizational or institutional culture determines the success or the failure in corporate governance. Institutional culture shows the goals of an organization. It directs the organization and institutional culture and the organization performance responses (Pandey, 2014). Parker and Bradley (2000) determine an essential relationship between institutional culture and organizational performance. Even so, Ramachandran et al. (2011) 
suggest that institutional culture gradually becomes a trend in public sector organizations. It is the malfunction or absence which becomes a serious concern.

The main purpose of this study is to obtain the organizational performance through success factors namely information quality, service quality, data quality, and system quality focusing on the organizational culture. Specifically, this study aims to analyze the effect of AIS successful factors on organizational performance. It also aims to analyze the influence of organizational culture and organizational performance in RAO, South Lampung Regency.

Focus on the organizational performance in Indonesia local goverernment context, the next section is highlight literature review related to the organizational performance, contingency theory, hypothesis development of each variables in this study.

\section{LITERATURE REVIEW}

\subsection{Contingency Theory}

Contingency theory is a theory which requires a leader to make appropriate adjustments related to his own leadership in any circumstances. This theory is put forward by Fiedler (1964). It is mentioned that a leader's performance is determined and seen from his understanding of the conditions he leads. This contingency theory focuses on the form of leadership as well as the understanding of the appropriate circumstance situations for a leader. The form of leadership can be elaborated with the enthusiasm of work as a motivational relationship. Work motivation focuses on achieving an objective, emphasizing the development and the close relationships of individuals. Then, the form of leadership can be adjusted to the happening situation and conditions. Contingency theory states that there are three factors influencing the occurrence of a situation faced by a leader. Those three are subordinate leader relations, performance structure, and position strength. The subordinate leadership relationship is linked to the group's atmosphere and self-confidence, loyalty, and interaction. Performance structure is more related to performance optimization. Study related to organizational performance using contingency theory has been conducted by several studies namely Saha et al. (2012) and Shagari et al. (2017). Then, this study also uses contingency theory to support the relationship among several independent variables (service quality, information quality, data quality, and system quality on the dependent variable (organization performance) and the moderation relationship for the independent relationship to the dependent.

\subsection{Hypothesis Development}

The development of hypotheses in this study is based on the success factors of AIS. The factors are believed to influence organizational performance. It is formulated as:

\section{Service Quality and Organizational Performance}

Gardin and Greve (2008) state that the basic meaning of contingency theory is that organizations should be adaptive. They should adapt to their contingency structures, such as the environment, organizational size, and business strategy. It aims that the organization is able to run well. Duncan and Elliott (2002) suggest that there is a beneficial relation between service quality and financial performance in a financial services organization. Kesuma et al. (2013) and Nazeer et al. (2014) identify a mutual relationship between service quality and business performance. They suggest the profit-seeking activities by providing services to possibly provide a greater strategic role for service quality. It is coupled with making a constant change toward better and premium prices, better customer value, and customer orientation as the benefits from the implementation of information technology. Also, others report some findings related to service quality on organizational performance with positive and significantly strong relationship using individual measurements (Weerakoon \& Wijavanayake, 2013; Khan \& Fasih, 2014; Ali et al. 2016). They examine the organizational performance as customer loyalty. They report a beneficial relationship is found according to service quality.

$\mathrm{H}_{1}$ : Service quality has a positive effect on organizational performance

\section{Information Quality and Organizational Performance}

In the previous information system study, Emery (1971) states that intrinsic value is not held by information but its value is only related to the effect on physical events. However, this has become a trigger (Lucas Jr. \& Nielsen, 1980). In terms of performance improvement, this study applies learning as the dependent variable to make an understanding of inventory using the system. It is because an Information Quality (IQ) problem delivers significant changes for companies which project superior performance, gain competitive advantage, or survive in the survival of the environment in contemporary business. 
Several previous and modern research studies have been conducted on the effects of information systems and using the size of an organization's performance and their dependent variables (Chang \& King, 2005; Bernroider, 2008; Gorla et al. 2010). At the organizational level, previous study conducted reveals that IQ affects organizational performance (Ali et al. 2016; Soudani, 2012).

$\mathrm{H}_{2}$ : Information quality has a positive effect on organizational performance.

\section{Data Quality and Organizational Performance}

Contingency theory suggests an organizational structure containing several factors including environmental conditions, business strategies, hierarchy in organizations, technology production, and forms of management (Ismail \& King, 2004). The quality and effectiveness of accounting information systems depend on the quality of inputs, outputs and processes. It shows the urge of data quality for the accounting information system successes as stated by Hubley (2011) and Wongsim and Gao (2010). A study by Rahayu et al. (2012) mentions that achieving effective works, data quality is required for an accounting information system. Thus, an accounting information system adoption needs to be considered. Both system quality and data quality are used for the decision-making activities in organizations (Wongsim \& Gao, 2010). In the study of Ahmad et al. (2013), it reveals the priority of data quality in any AIS. It indicates that the organizations should apply it as the main reference. Emeka-Nwokeji (2012) states that the quality of data in accounting information systems should refer to the size of the data quality in organizations and contribute to the effectiveness of accounting information systems. Saleh (2013) finds a strong relationship between data quality and auditor internal perceptions. Previous study related to data quality as a success factor in organizational performance is noticed to have a positive effect (Ahmad et al. 2013; Emeka-Nwokeji, 2012).

$\mathrm{H}_{3}$ : Data quality has a positive effect on organizational performance.

\section{System Quality and Organizational Performance}

Contingency theory is to assess company performance which depends on the suitability between contextual factors as an organization (Cadez \& Guilding, 2008). The system quality contributes to the usage, user convenience and individual performance. It consequently affects performance in the organization (DeLone \& McLean, 1992). There is an important prerequisite to benefit from the organization. It is a well-developed and implemented system. Gorla et al., (2010) and Hsieh and Wang, (2007) report that system quality has a positive effect for the organizations. Kositanurit et al. (2006) finds a significant relationship between the perceived ease of use and performance. However, reliability and performance for individual ERP system users have not affected each other. Bharati and Chaudhury (2015) find mutual relationships among system quality, measurement using reliability, flexibility, ease of use, and the convenience of access for satisfaction in decision making. This is in line with Ali et al. (2016) who delivers findings related to the effect of system quality on organizational performance. It suggests that the system quality is strongly associated with net benefits at the organizational level.

$\mathrm{H}_{4}$ : The quality of the system has a positive effect on organizational performance.

\section{Organizational Culture as Moderator}

Organizational culture is a condition in which a strong look is made to make progress-engineered mechanisms to carry out several considerations in the organization (Akinnusi, 1991). Ramachandra et al. (2010) mention that the organizational culture (OC) significantly influences the success of promoting organizational change. The leadership models desire the behaviors. In fact, the implementation of the first change should be from the lead organizations to the general workforce to strengthen their commitment of work. It purposes that there will be no negative impact on the change. The study conducted by Ali et al. (2016) confirms the findings that the culture of organizations helps increase the performance of the organizations by relating information quality, data quality and system quality; and weakening service quality.

Organizational activities and steps to obtain a decision formulation are directed from the culture of the organization. Thus, it supports the welfare of the organization. Organizational culture is considered as the creation of human resource management practices, or managerial practices affecting the company boards, shareholders, or other stakeholder preferences. The performance of the system has the effect on the relationship between organizational commitment and work performance (Babulak, 2006; Buller \& McEvoy, 2012; Özçelik \& Aydinli, 2012). The findings of this invention have been adjusted to several findings in the past which have an effect on the system quality, as previously reported. According to Babulak (2006) performance can be made by employees or individuals at work sites. Personal factors can also exert influence in a performance are knowledge, abilities, skills, motivation and attitudes. Shift rules to provide better performance output in the workplace are a system of performance management dealing with colleagues and superiors, performance goals, company 
encouragement, and action or award to recognize outstanding performance. These factors include: the application of organizational culture, and the determining factor is individual organizations in accordance with organizational goals.

$\mathrm{H}_{5}$ : Organizational culture moderates the relationship between service quality and organizational performance.

$\mathrm{H}_{6}$ : Organizational culture moderates the relationship between information quality and organizational performance.

$\mathrm{H}_{7}$ : Organizational culture moderates the relationship between data quality and organizational performance.

$\mathrm{H}_{8:} \quad$ Organizational culture moderates the relationship between system quality and organizational performance.

\section{DATA AND METHODOLOGY}

This study aims to analyze the influence of the success factors of AIS (service quality, information quality, data quality, and system quality) and the influence of organizational culture in the organizational performance. The population in this study is 29 RAO in South Lampung Regency. The samples of this study taken from three divisions. The sample taken from the Regional Secretariat is the Regional Secretary, Section Assistant and Section Chief. The sample taken from the DPRD Secretariat is the DPRD Secretary and the Head of the Department. The sample taken from the Office and Agency is the Head of Service or Head of Agency and the Office Secretary or Agency Secretary. In this study, the sampling method applies saturated samples with a quantitative approach. A total of 77 questionnaires were distributed, as many as 67 questionnaires were used with complete conditions, and 10 questionnaires were not returned.

The collected data was then analyzed using Structural Equation Modeling (SEM) and computer software supported by the application of Partial Least Square (PLS) version 3.0. The dependent variable is the organizational performance measured by the indicators adopted from Ali et al. (2016).

The independent variable in this study is the quality of service measured by indicators adopted from Kheng (2010), information quality measured by indicators adopted from Ali et al. (2016), data quality measured by indicators adopted from Ali et al. (2016), and the quality of the system as measured by indicators adopted from the Shagari et al. (2017). The moderating variable is the organizational culture measured by indicators adopted from Aswar and Saidin (2018). A Likert scale with 5 levels ( $1=$ Strongly Disagree, $2=$ Disagree, $3=$ Neutral, $4=$ Agree, $5=$ Strongly Agree) was applied in this study.

\section{FINDINGS AND DISCUSSIONS}

Before testing the hypothesis, validity and reliability tests are done first. The validity testing is done by observing the average variance extracted (AVE) with recommended value above 0.5 . The reliability test is done by observing the value of Composite Reliability and Cronbach Alpha. The Composite Reliability value for all constructions is above 0.7 . It means that all constructs in this study are estimated to meet the criteria and the suggested values in Cronbach's Alpha above 0.6 is for all constructions (Ghozali, 2014). Furthermore, to assess the model with PLS is by checking the R-Square (R2) for each latent dependent variable (Ghozali, 2014). The results of validity and reliability tests can be seen in the following table.

Table 1: The Results of Validity and Reliability Test

\begin{tabular}{cccc}
\hline $\mathrm{R}^{2}=0,336$ & AVE & Composite Reliability & Cronbach's Alpha \\
\hline Variable & 0,517 & 0,863 & 0,816 \\
OC & 0,577 & 0,890 & 0,854 \\
DQ & 0,733 & 0,943 & 0,927 \\
IQ & 0,600 & 0,881 & 0,830 \\
OP & 0,510 & 0,892 & 0,865 \\
SQ & 0,545 & 0,892 & 0,856 \\
QS & &
\end{tabular}

The lowest value of AVE is 0.510 in the independent variable that is service quality and all variables are valid. The lowest value of Composite Reliability in this research model is 0.863 for organizational culture variables so that all variables have good reliability from each construct. The lowest value of Cronbach's Alpha is 0.816 in organizational culture so that all variables show good reliability of each construct as well.

R-Square (R2) seen from Adjusted R-Square organizational performance is equal to 0.336 . It indicates the independent latent variables of service, information, data, and system qualities. The moderation variables namely organizational culture explains the dependent latent variables namely organizational performance by $33.6 \%$. The remaining $66.4 \%$ is explained by other factors out of this study which has not been considered. 
Table 2: The Results of Hypotheses Test - Bootstrapping Algorithm

\begin{tabular}{|c|c|c|c|c|}
\hline Hypotheses & Variables & Path Coeficients & T Statistics & P Value \\
\hline H1 & SQ-> OP & 0,365 & 2,564 & 0,011 \\
\hline H2 & IQ -> OP & 0,073 & 0,428 & 0,669 \\
\hline H3 & DQ -> OP & 0,155 & 0,907 & 0,365 \\
\hline H4 & QS -> OP & 0,071 & 0,386 & 0,699 \\
\hline H5 & OC.SQ -> OP & $-0,121$ & 0,641 & 0,522 \\
\hline H6 & OC.IQ - OP & $-0,111$ & 0,458 & 0,647 \\
\hline H7 & OC.DQ -> OP & 0,155 & 0,745 & 0,457 \\
\hline H8 & OC.OS -> OP & 0,342 & 1,549 & 0,122 \\
\hline
\end{tabular}

The results of testing the hypothesis are by applying Structural Equation Modeling (SEM) and by using computer software supported by the Partial Least Square (PLS) version 3.0 application. Table 2 shows that service quality (SQ, $t=2.564$ and $p$ value $=0.011)$, information quality $(I Q, t=0.428$ and $p$-value $=0.669)$, data quality $(D Q, t=0.907$ and $p$-value $=0.365)$, the quality of the system $(\mathrm{QS}, \mathrm{t}=0.386$ and $\mathrm{p}$-value $=0.699)$. It means that $\mathrm{H} 1$ is accepted and $\mathrm{H} 2, \mathrm{H} 3$, and $\mathrm{H} 4$ are rejected. Organizational culture in moderating service quality $(O C . S Q, t=0.641$ and $p$-value $=0.522)$ does not affect organizational performance which means that $\mathrm{H} 5$ is rejected. Organizational culture in moderating information quality $(\mathrm{OQ} . \mathrm{IQ}, \mathrm{t}=0.458$ and $\mathrm{p}$-value $=0.647$ ) does not affect organizational performance which means that $\mathrm{H} 6$ is rejected. Organizational culture in moderating data quality $(O C . D Q, t=0.745$ and $p$-value $=0.457)$ does not affect organizational performance which means that $\mathrm{H} 7$ is rejected. Organizational culture in moderating the quality of the system (OC.QS, $t=1.549$ and $p$-value $=0.122$ ) does not affect organizational performance which means that $\mathrm{H} 8$ is rejected.

Service quality has a positive influence on organizational performance. It shows that better service quality increases the organizational performance supported by Weerakoon and Wijavanayake (2013), Khan and Fasih (2014), and Ali et al. (2016). The results of this study indicate the good quality of services including reliability, assurance, direct evidence, friendly attitude of officers, empathy, and responsiveness related to the state of existing human resources, infrastructure and work facilities producing good organizational performance. Then, it is in accordance with the contingency theory focusing on the form of leadership and understanding of the situation with the appropriate circumstances by a leader. The form of leadership is explained as a work impulse or as a relationship boost. Work motivation focuses more on achieving goals, improvement and personal relationships.

The quality of information has no effect on organizational performance. It shows that the quality of information has not been maximized yet. Thus, organizational performance declines. The results of this study are not supported by studies which reveal information quality influencing organizational performance such as Bharati and Chaudhury (2015), Ali et al. (2016), Soudani (2012). Then, there is the lack of implementing good information quality including accuracy, timeliness, and format to facilitate human resources at work and produce unfavorable outputs. It is not in accordance with the contingency theory which serves as the basis for developing hypotheses. The results of the study refer to the internal dependence to meet the need of sharing information across national organizational functions, organizational formalization, and interdependence of organizations in terms of resource interests and accessibility, significant effects on requirements for organizational coordination and national system control.

Data quality presents no effects on organizational performance. This proves that data quality has not been maximized. As a result, organizational performance declines. The results of this study are supported by Ali et al. (2016) revealing that there are no relations between data quality and organizational performance. However, the results of this study are not supported by studies reporting that data quality affects organizational performance (Ahmad et al. 2013; Emeka-Nwokeji, 2012). It is caused by the lack of implementation to produce high quality data such as: accuracy, completeness, renewal, consistency, relevant human resources facilities at work and unfavorable output productions. Then, it is not in accordance with the contingency theory suggesting the existence of an organizational structure. There are several contextual factors namely environmental conditions, the existence of a business plan, organizational mechanisms, production for technology, and forms of management (Ismail \& King, 2004).

The system quality performs no effect on the performance of the organization. It shows unmaximized quality of the data which decreases the organizational performance. The results of this study are supported by Shagari et al. (2017) revealing the quality of the system with no impact on organizational performance. However, it is not supported by research revealing that the quality of the system influences organizational performance such as Bharati and Chaudhury (2015) and Ali et al. 
(2016). It causes the system not to integrate, and the bias data. It is concluded that there is a poor implementation of the system to support the processing of inputs and outputs such as: security, ease of use, efficiency used by human resources while working and producing unfavorable outputs. Thus, it is not in accordance with the contingency theory explaining that the accounting information system needs to adapt to the specific desires. It considers the environment and organizational structure in an organization (Dandago \& Rufai, 2014). Contingency theory is to assess company performance depending on the suitability between contextual factors as an organization (Cadez \& Guilding, 2008).

Organizational culture does not balance the service quality and organizational performance. It indicates that organizational leaders do not apply good organizational culture. The results of this study are in line with Ali et al. (2016) explaining that the organizational culture becomes a moderating variable to weaken the organizational performance by interacting with service quality. This is not according to Katou and Budhwar (2010) examining a causal relationship of HRM performance into Greek utilizing contingency theory, resource-based views as well as ability, motivation and opportunity. Leaders lack a good organizational culture which includes innovation and risk developments, attention to detail, output orientation, people and team orientations, aggressiveness, stability, and influencing employees to provide public information to the public.

The results of this study are not in line with Ali et al. (2016). It mentions organizational culture as a moderating variable which strengthens organizational performance by interacting with information quality. However, this is not in line with contingency theory which urges an organization to take several considerations for workers, the managerial department influencing company boards, shareholders, or other stakeholders' preferences. The leaders lack to implement good organizational culture.

This study is also not in accordance with contingency theory. It is a theory which explains that adaptation to the specific desired decisions is required for accounting information systems. The decisions are made by considering the environment and organizational structure (Dandago \& Rufai, 2014). Thus, it is related to the quality of the data processed needed for the process of accounting information systems to support the organizational performance achievement. Özçelik and Aydinli (2006) explain that the performance of a system has an influence on organizational agreements and performance in the work environment. This is not in line with contingency theory according to Gordon and Miller (1976). It lays the basic framework to consider the accounting information systems from a contingency perspective. Accounting information systems need to be adaptive to the specific decisions. Then, leaders are assumed not to apply good organizational culture related to innovation and risk development; attention to detail; orientation of output, public, team; aggressiveness; stability, and their influencing employees to provide data reliability to the user interests.

\section{CONCLUSION}

The study is to discover the impacts of service quality, information quality, data quality, system quality of public sector organization and organizational culture performances as a moderating variable. Based on the results of the analysis done with a series of hypothesis testing, it summarizes the quality of service has affected the performance of public sector organizations positively. This shows that the better system quality improves the performance of public sector organizations in each each RAO at the Regional Secretariat (Regional Secretary, Section Assistant and Section Chief), at the DPRD Secretariat (DPRD Secretary and Section Head), at Office and Agency (the Office Head or Agency Head and the Office Secretary or Agency Secretary)

The quality of information, data, and system do not affect the performance of public sector organizations positively. This shows that if the public sector organization gives low information to the public, processes data and uses facilities integrated with the agency system, the performance of public sector organizations in each RAO will decline.

Organizational culture does not moderate the relationship between $\mathrm{SQ}, \mathrm{IQ}, \mathrm{DQ}, \mathrm{QS}$ and $\mathrm{OC}$ of public sector organizations. This shows that the organizational culture adopted and disseminated weakens the relationship between service quality, information quality, data quality, system quality on the performance of public sector organizations as the sample in this study lacks understanding of organizational culture well. Thus, organizational culture weakens the relationship between $S Q, I Q, D Q$, QS and OC of public sector organizations.

The limitations of this study include: RAO objects are only in the South Lampung Regency Government; the time for respondents to explore more information related to the occupation and occupation is limited; sample taken in Regional Secretariat is only from the Regional Secretary, Section Assistant and Section Chief; sample taken in the DPRD Secretariat is only from the DPRD Secretary and the Section Head, sample taken at the Office and Agency is only from the Head of Service or Agency Head and the Office Secretary and Secretary or Agency Secretary in the South Lampung Regency. In addition to the 
dissemination process, Direct questionnaires to the location of each RAO in the Regional Government of South Lampung Regency was conducted during the Covid-19 virus pandemic. The respondents did not work every day. The sample majority is the respondents owning post-graduate education (S2) continued with bachelor (S1) or doctorate (S3) - only 1 person.

Suggestions for the Regional Government of South Lampung Regency are expected to be more active to provide services, information, data processing, using integrated systems to the community. Each RAO and RAO leaders and staff who hold positions to provide good leadership to subordinates need to be aware of the organizational culture to improve organizational performance. Then, the next study is expected to be able to examine organizational performance materially and add other independent variables such as employee motivation, employee performance, self-efficacy, and to use empowerment moderation variables. In addition, researchers are able to replace the object of research into RAO or private organizations in other regions in Indonesia.

\section{REFERENCES}

Ahmad, M., Ayasra, A. \& Zaideh, F. (2013). Issues and problems related to data quality in AIS implementation. International Journal of Latest Research in Science and Technology, 2(2), 17-20.

Akinnusi, D.M. (1991). Personnel management in Africa: A comparative analysis of Ghana, Kenya and Nigeria. In C. Brewster \& S. Tyson (Eds.), International comparisons in human resource management (pp. 159-171). London: Pitman.

Ali, B., J.A. Omar, W., A.W. \& Bakar, R. (2016). Accounting Information System (Ais) Andorganizational Performance: Moderating Effect of Organizational Culture. International Journal of Economics, Commerce And Management, 4 (4),58-75.

Aswar, K., \& Saidin, S. Z. (2018). Accrual Accounting Adoption In Java Municipalities: An Empirical Investigation. International Journal of Business and Economic Sciences Applied Research (IJBESAR), 11(3), 24-30.

Babulak, E. (2006). Quality of service provision assessment in the healthcare information and telecommunications infrastructures. International Journal of Medical Informatics, 75, 246-252.

Badan Pemeriksa Keuangan, (2017). Ikhitisar Hasil Pemeriksaan Semester II 2017. Jakarta.

Bernroider, E. W. (2008). IT governance for enterprise resource planning supported by the DeLone-McLean model of information systems success. Information \& Management, 45(5), 257-269.

Bender, D. H. (1986). Financial impact of information processing. Journal of Management Information Systems, 3(2), $22-32$.

Bharati, P. \& Chaudhury, A. (2015). Product customization on the web: an empirical study of factors impacting choiceboard user satisfaction. Information Resources Management Journal, 19(2), 69-81.

Bradley, R. V., Pridmore, J. L. \& Byrd, T. A. (2006). Information systems success in the context of different corporate cultural types: an empirical investigation. Journal of Management Information Systems, 23(2), 267-294.

Buller, P. F. \& McEvoy, G. M. (2012). Strategy, human resource management and performance: Sharpening line of sight. Human resource management review, 22(1), 43-56.

Cadez, S., \& Guilding, C. (2008). An exploratory investigation of an integrated contingency model of strategic management accounting. Accounting, Organizations and Society, 33(7-8), 836-863.

Chang, J. \& King, W. R. (2005). Measuring the performance of information systems: a functional scorecard. Journal of Management Information Systems, 22(1), 85-115.

Dandago, K., \& Rufai, A. (2014). Information Technology and Accounting Information System in the Nigerian Banking Industry. Asian Economic and Financial Review, 4(5), 655-670.

DeLone, W. H. \& McLean, E. R. (1992). Information systems success: The quest for the dependent variable. Information systems research, 3(1), 60-95.

Duncan, E. \& Elliott, G. (2002). Customer service quality and financial performance among Australian retail financial institutions. Journal of Financial Services Marketing, 7(1), 25-41.

Emeka-Nwokeji, N. (2012). Repositioning accounting information system through effective data quality management: A framework for reducing costs and improving performance. International Journal Of Scientific Technology Research, 1(10), 86-94.

Emery, J. C. (1971). Cost/benefit analysis of information systems. Society for Management Information Systems.

Fiedler, F. E. (1964). A theory of leadership effectiveness. In L. Berkowitz (Ed.) Advances in experimental social psychology. New York: Academic Press. 
Gardin, J., and Greve, J. 2008. The Appropriateness of Statistical Methods for testing Contingency Hypotheses in Management Accounting Research. Accounting, Organizations and Society, 33(5), 995-1009.

Ghozali, I. (2014). Structural Equation Modeling, Metode Alternatif dengan Partial Least Square (PLS). Edisi 4. Semarang : Badan Penerbit Universitas Diponegoro.

Gordon, L., \& Miller, D. (1976). A contingency framework for the design of accounting information systems. Accounting Organizations and Society, 1(1), 59-69.

Gorla, N., Somers, T. M. \& Wong, B. (2010). Organizational impact of system quality, information quality, and service quality. The Journal of Strategic Information Systems, 19(3), 207-228.

Gowan, M., Seymour, J., Ibarreche, S., \& Lackey, C. (2001). Service quality in public agency: same expectations but different perceptions by employees, managers and customers. Journal of Quality Management, 6, 275-291.

Hamilton, S. \& Chervany, N. L. (1981). Evaluating information system effectiveness-Part I: Comparing evaluation approaches. MIS quarterly, 55-69.

Henri, J.F. (2006), Organizational culture and performance measurement system. Accounting, Organization and Society, 31, 77-103.

Hubley, J. (2011). Data Quality: The Foundation for Business Intelligence. Hussein, A. M. (2011). Use Accounting Information System as Strategic Tool to Improve SMEs' Performance in Iraq Manufacturing Firms.

Hsieh, J. P.-A. \& Wang, W. (2007). Explaining employees' extended use of complex information systems. European Journal of Information Systems, 16(3), 216-227.

Indonesia. Kementrian Pendayagunaan Aparatur Negara, (2004). Keputusan Menteri Pendayagunaan Aparatur Negara Nomor KEP/25/M.PAN /2/2004 tentang Pedoman Umum Penyusunan Indeks Kepuasan Masyarakat Unit Pelayanan Instansi Pemerintah. Jakarta: Kementrian Pendayagunaan Aparatur Negara Republik Indonesia.

Indonesia. Kementrian Pendayagunaan Aparatur Negara, (2009). Undang-Undang Republik Indonesia Nomor 25 Tahun 2009 tentang Pelayanan Publik. Jakarta: Kementrian Pendayagunaan Aparatur Negara Republik Indonesia.

Ismail, N.A., \& King, M. (2005). Firm Performance and AIS alignment in Malaysian SMEs. International Journal of Accounting Information Systems. 6(4), 241-259.

Kanji, G., \& Moura E Sá, P. (2007). Performance Measurement and Business Excellence: The Reinforcing Link for the Public Sector. Total Quality Management \& Business Excellence, 18(1-2), 49-56.

Katou, A. A., \& Budhwar, P. S. (2010). Causal relationship between HRM policies and organisational performance: Evidence from the Greek manufacturing sector. European Management Journal, 28(1), 25-39.

Kesuma, I. A. W., Hadiwidjojo, D., Wiagustini, N. L. P. \& Rohman, F. (2013). Service Quality Influence on Patient Loyalty: Customer Relationship Management as Mediation Variable (Study on Private Hospital Industry in Denpasar). International Journal of Business and Commerce, 2(12), 1-14.

Khan, M. M. \& Fasih, M. (2014). Impact of service quality on customer satisfaction and customer loyalty: Evidence from banking sector. Pakistan Journal of Commerce and Social Sciences, 8(2), 331-354.

Kheng, L. L. (2010). The Impact of Service Quality on Customer Loyalty: A Study of Banks in Penang, Malaysia. International Journal of Marketing Studies, 2(2), 57-66.

Kositanurit, B., Ngwenyama, O. \& Osei-Bryson, K.M. (2006). An exploration of factors that impact individual performance in an ERP environment: an analysis using multiple analytical techniques. European Journal of Information Systems, 15(6), 556-568.

Lucas Jr, H. C. \& Nielsen, N. R. (1980). The impact of the mode of information presentation on learning and performance. Management Science, 26(10), 982-993.

Melkers, J., \& Willoughby, K. (2005). Models of Performance-Measurement Use in Local Governments: Understanding Budgeting, Communication, and Lasting Effects. Public Administration Review, 65(2), 180-190.

Nazeer, S., Zahid, M. M. \& Azeem, M. F. (2014). Internal Service Quality and Job Performance: Does Job Satisfaction Mediate? Journal of Human Resources, 2(1), 41-65.

Özçelik, O. A. \& Aydinli, F. (2006). Strategic role of HRM in Turkey: a three-country comparative analysis. Journal of European Industrial Training, 30(4), 310-327.

Pandey, P. (2014), Organisational culture - A root to prosperity. Management Insight, 10(1), 74-80. 
Parker, R., Bradley, L. (2000), Organisational culture in the public sector: Evidence from six organisations. International Journal of Public Sector Management, 13(2), 125-141.

Peltier, J. W., Zahay, D., \& Lehmann, D. R. (2013). Organizational Learning and CRM Success: A Model for Linking Organizational Practices, Customer Data Quality, and Performance. Journal of Interactive Marketing, 27(1), 1-13.

Peraturan Menteri Dalam Negeri Nomor 13 Tahun 2006 tentang Pedoman Pengelolaan Keuangan Daerah.

Ramachandran, S., D, Chong, S., C \& Ismail, H. (2010). Organisational culture An exploratory study comparing faculties perspectives within public and private universities in Malaysia. International Journal of Educational Management, 25 (6), 615-634.

Rahaman, M. M., Abdullah, M. \& Rahman, A. (2011). Measuring service quality using SERVQUAL model: A study on PCBs (Private Commercial Banks) in Bangladesh. Business Management Dynamics, 1(1), 1- 11.

Rahayu, S. K. \& others. (2012). The Factors That Support The Implementation Of Accounting Information System: A Survey In Bandung And Jakarta'S Taxpayer Offices. Journal of Global Management, 4(1), 25-52.

Saha, P., Nath, A. K., \& Salehi-Sangari, E. (2012). Evaluation of government e-tax websites: An information quality and system quality approach. Transforming Government: People, Process and Policy, 6(3), 300-321.

Saleh, F. M. (2013). Critical success factors and data quality in accounting information systems in Indonesian cooperative enterprises: An empirical examination. Interdisciplinary Journal of Contemporary Research in Business, 5(3), 321-338.

Seddon, P. \& Kiew, M. Y. (1996). A partial test and development of DeLone and McLean's model of IS success. Australasian Journal of Information Systems, 4(1), 90-109.

Shagari, S.L., Abdullah, A., \& Saat, R.M. (2017). Accounting information systems effectiveness: Evidence from the Nigerian Banking Sector. Interdisciplinary Journal of Information, Knowledge, and Management, 12, 309-335.

Slaughter, S. A., Harter, D. E., \& Krishnan, M. S. (1998). Evaluating the cost of software quality. Communications of the ACM, 41(8), 67-73.

Soudani, S. N. (2012). The Usefulness of an Accounting Information System for Effective Organizational Performance. International Journal of Economics and Finance, 4(5).

Verbeeten, F. H. M., \& Speklé, R. F. (2015). Management Control, Results-Oriented Culture and Public Sector Performance: Empirical Evidence on New Public Management. Organization Studies, 36(7), 953-978.

Weerakoon, W. M. L. P., \& Wijavanayake, W. M. J. (2013). Impact of the information systems service quality on performance of IT sector organizations in Sri Lanka. 2013 International Conference on Advances in ICT for Emerging Regions (ICTer).

Wongsim, M. \& Gao, J. (2010). Data Quality issues in Accounting Information Systems Adoption-Theory building. Networked Computing and Advanced Information Management (NCM). Sixth International Conference. 224-230.

Yasin, M., Correia, E., \& Lisboa, J. (2004). The profitability of customer-targeted quality improvement efforts: an empirical examination. The TQM Magazine, 16(1), 45-49.

\section{APPENDIX 1: Survey Questionnaire}

\begin{tabular}{|c|c|}
\hline Variable & Item measure \\
\hline Performance Measurement & $\begin{array}{l}\text { 1. Carry out part of the duties or service authority in my field. } \\
\text { 2. Formulate technical policies according to my field of work. } \\
\text { 3. Compile data about work in my field of work. } \\
\text { 4. Leading, developing and mentoring my subordinates. } \\
\text { 5. Planning and implementing programs in my field of work. } \\
\text { 6. Provide direction and training to my subordinates. } \\
\text { 7. Assess and measure the performance of my subordinates. }\end{array}$ \\
\hline Service quality & $\begin{array}{l}\text { 1. } \\
\text { 2. Odequate physical equipment. } \\
\text { 3. Management procedure is clear. } \\
\text { 4. Officers master the problem. } \\
\text { 5. The seriousness and patience of the officer. } \\
\text { 6. Officer response speed. } \\
\text { 7. Officer alacrity. } \\
\text { 8. Telephone service. } \\
\text { 9. }\end{array}$ \\
\hline
\end{tabular}




\begin{tabular}{|c|c|c|}
\hline & $\begin{array}{l}10 . \\
11 . \\
12 . \\
13 . \\
14 .\end{array}$ & $\begin{array}{l}\text { Clerk solve problem on time. } \\
\text { Officer credibility. } \\
\text { Hear every complaint well. } \\
\text { Friendly and polite attitude of officers. } \\
\text { Understanding of user problems. }\end{array}$ \\
\hline Information Quality & $\begin{array}{l}1 . \\
2 . \\
3 . \\
4 . \\
5 . \\
6 .\end{array}$ & $\begin{array}{l}\text { precise and accurate data } \\
\text { data according to activities } \\
\text { Timely delivery of data } \\
\text { The data submitted is up to date } \\
\text { The information presented is easy to read } \\
\text { There is a manual book }\end{array}$ \\
\hline Data Quality & $\begin{array}{l}1 . \\
2 . \\
3 . \\
4 . \\
5 . \\
6 . \\
7 . \\
8 .\end{array}$ & $\begin{array}{l}\text { The data presented is in accordance with reality } \\
\text { The data presented are not biased } \\
\text { The number of publications is quite a lot } \\
\text { Publication types/ titles are quite diverse } \\
\text { The data presented is as needed } \\
\text { Complete data series } \\
\text { Data display is easy to understand } \\
\text { The data presented is consistent }\end{array}$ \\
\hline System Quality & $\begin{array}{l}1 . \\
2 . \\
3 . \\
4 . \\
5 . \\
6 .\end{array}$ & $\begin{array}{l}\text { User login is required to access agency facilities online } \\
\text { Automatic logout is activated after a period of inactivity } \\
\text { Anti firus software does not prevent the system from catching viruses } \\
\text { Our AIS is not regularly checked and managed by IT unit staff } \\
\text { The user interface of our agency information system is easy to use } \\
\text { The tutorials or instructions given by our AIS help to use the system } \\
\text { easily } \\
\text { User interface design by our AIS is user friendly } \\
\text { I understand every AIS function } \\
\text { I'm not familiar with our AIS interface } \\
\text { Our AIS user interface items are easy to understand } \\
\text { Our AIS really helps my work efficiency } \\
\text { AIS processing speed helps me to get my work done very fast }\end{array}$ \\
\hline Organizational Culture & $\begin{array}{l}1 . \\
2 . \\
3 .\end{array}$ & $\begin{array}{l}\text { At work I am required to think innovatively } \\
\text { I was always required to be brave } \\
\text { Every time I do my job, I always prioritize accuracy, analysis and } \\
\text { attention to detail } \\
\text { So far, I feel that management in the agency is prioritizing results and } \\
\text { outputs } \\
\text { so far, I feel that decisions taken by management consider the impact } \\
\text { of outputs on employees } \\
\text { The work that I do tends to prioritize tiem performance } \\
\text { Everyone who works is more aggressive and competitive than casual } \\
\text { The existing job always emphasizes stability rather than growth }\end{array}$ \\
\hline
\end{tabular}

